\title{
A Positive Impact on Coastal and Marine Environment By Implementation of Biofloc System
}

\author{
Amarnath Dogiparti* \\ Department of Marine Living Resources, Andhra University, India \\ *Corresponding author: Amarnath Dogiparti, Department of Marine Living Resources, Andhra University, India

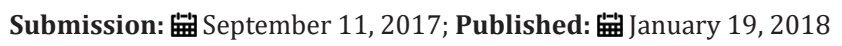

\begin{abstract}
Aquaculture industry is increased extremely from recent years due to requirement and demand. Similarly, the requirement of feed ingredients like fish meal and fish oil demand also increased extremely. Mostly these industries depending on unconsumed or commercially less demand, minor pelagic fin fish which are containing high percentage of bones and fat. The capturing of massive fishery resources changes the marine habitat and biodiversity. In Biofloc system, the nutrients are recycled and the discharge waste contains minimal nutrient levels. Worldwide, among the countries, few are using the Biofloc system which is beneficial to the one who cultivates, as well as to the ecosystem.
\end{abstract}

Keywords: Aquaculture; Massive capture; Biofloc; Marine habitat and biodiversity

\section{Introduction}

From last decade the aquaculture sector is increased vastly with advanced technologies, good culture management and bio security measures etc. The expansion of aquaculture industry will also restrict in feature course due to land cost or land availability [1,2]. More over the feed industries must depends on fish meal or fish oil for the synthesis of different types of feeds for aquatic organisms [3]. For these ingredients in turn depends on various types of fishery resources. The demand of fish meal and fish oil increasing due to requirement for the production of aquatic feeds. The annual production of fish meal is 6.3 million tonnes and 1 million tonne of fish oil produced from the 400 production plants by utilizing 33 million tonnes of fish and trimmings [4]. From the $12 \mathrm{~kg}$ of raw fish grade extract $2.4 \mathrm{~kg}$ of fish meal and $1 \mathrm{~kg}$ of fish oil [5]. Generally the feed industries preferred fish meal and its oil by the reason of containing high value of proteins, essential amino acids, minerals and omega-3 fatty acids [6]. The advanced technology is developing during recent days in aquaculture industry for more profits. Among them, the Biofloc system (BFT) is one of the method and in this is technique, the nitrogen wastes were recycled and produced organic protein in situ through microbes and it minimize the food conversion ratio (FCR) levels. BFT system is considering as efficient alternative system due to nutrients will be continuously recycled and reused. The discharges are causes direct impact to marine, estuarine or creek environment without BFT system and lead to eutrophication or shows impact on wild stock by toxic chemicals or diseases. The indirect impact could be shows on environmental which cause the habitat loss and niche space $[7,8]$. The capturing of various types of fishery resources from shows effect on habitat change and also biodiversity because of the marine ecosystem is size-structured based food web which means change in the size of population and abundance will leads to change in the quantity and type of prey consumed [9].

\section{Exploitation of Fishery Resources for the Production of Feed}

The aquaculture feed produced companies required fish meal and fish oil which is majorly from capture fishery resources. During 2004, 95 million tonnes of fish and shell fishery were captured globally. Among them 34.8 million tonnes were utilized for nonfood uses i.e. for the production of fish meal and fish oil for animal feed synthesis [10]. The major capturing species were herring, sardines, mackerel, pilchards, anchovies, sand eels and other noncommercial species. The capturing of Krill was 80,000 tonnes/year for feeding farmed fish and crustaceans [11]. In 2006, 3724 tonnes of fish meal and 835 thousand tonnes of fish oil were consumed by aquaculture industries [12]. The global fisheries production was reached 167.2 million tonnes (Mt) in 2014, with 73.8Mt from aquaculture and $93.4 \mathrm{Mt}$ from capture fishery. In capture fishery 81.5 Mt from marine waters and remaining from inland waters. The non-food products were reached to $21 \mathrm{Mt}$ for the various purposes like pharmaceutical industries, aquatic feed raw materials and for live stock feds. Of this $21 \mathrm{Mt}, 15.8 \mathrm{Mt}$ utilized as fishmeal and rest for fish oil. In 2015, fish meal and fish oil were produced 4.76Mt and $0.856 \mathrm{Mt}$ respectively by utilizing the $13.9 \mathrm{Mt}$ of whole fish, $3.75 \mathrm{Mt}$ of wild capture by-products and $1.94 \mathrm{Mt}$ of aquaculture by-products [13].

\section{Biofloc Technology (BFT) and Its Positive Impact}

First BFT system was developed at Ifremer-COP (French 
Research Institute for Exploitation of the Sea, Oceanic Center of Pacific) on different penaeid shrimps like Litopenaeus vannamei, L. stylirostris, Penaeus monodon and Fenneropenaeus merguiensis [14-16]. The BFT system is nothing but the activated suspension technique which means reutilization of nutrients in the pond bottom. During the culture system, animals excreting more nitrogenous waste due to usage of high level of proteins in feed. By using different biofileters can remove these wastes but it involved high cost. In case of BFT system, the inorganic immobilised nitrogen wastes can be utilized by the heterotrophic bacteria and converted into useful organic protein contents in situ by the addition of carbon source [17]. For the growth of heterotrophic bacteria maintain high quality C:N (20:1) ration levels for easily uptake of inorganic nutrients [18-20]. The various carbon sources have to use to increase the carbon levels in pond and is varies on the cultured species like Macrobrachium rosenbergii (Acetates, Tapioca, Glucose, Glycerol and Glycerol with Bacillus), Penaeus monodon (Cassava meal), Tilapia (Wheat flour, Cellulose), Litopenaeus vannamei (Dextrose and Tapioca) [21]. In Biofloc system, maximise the utilization of wastes and recycled the nutrients levels [22]. The growth of aquatic organisms mainly based on the percentage of protein in the feed in pellets and is containing 24-28\%. By using the Biofloc system the can increase protein levels up to $38 \%$ and also can provide free amino acids such as alanine, glutamine, arginine and glycine which are acts as attractants also [23-25] and also containing essential fatty acids, minerals and vitamin ' $\mathrm{C}$ ' which enhances the not only growth and also the immune system [22,26,27]. During the culture of cat fish also observed specific growth rate and low FCR levels with Biofloc technology [28]. The BFT system implemented ponds shown low FCR and also with good survival rates $[29,30]$. The dried Biofloc contains quality protein and replaces the soya bean meal or fish meal in aqua feeds. The development of BFT will also helpful to prevent diseases from incoming waters due to zero water exchange [31]. Finally, the BFT system will decrease the production cost, beneficial to cultured species to enhance the growth, survival rate and prevention of diseases and also eco friendly.

\section{Aquaculture Impact on Marine Environment}

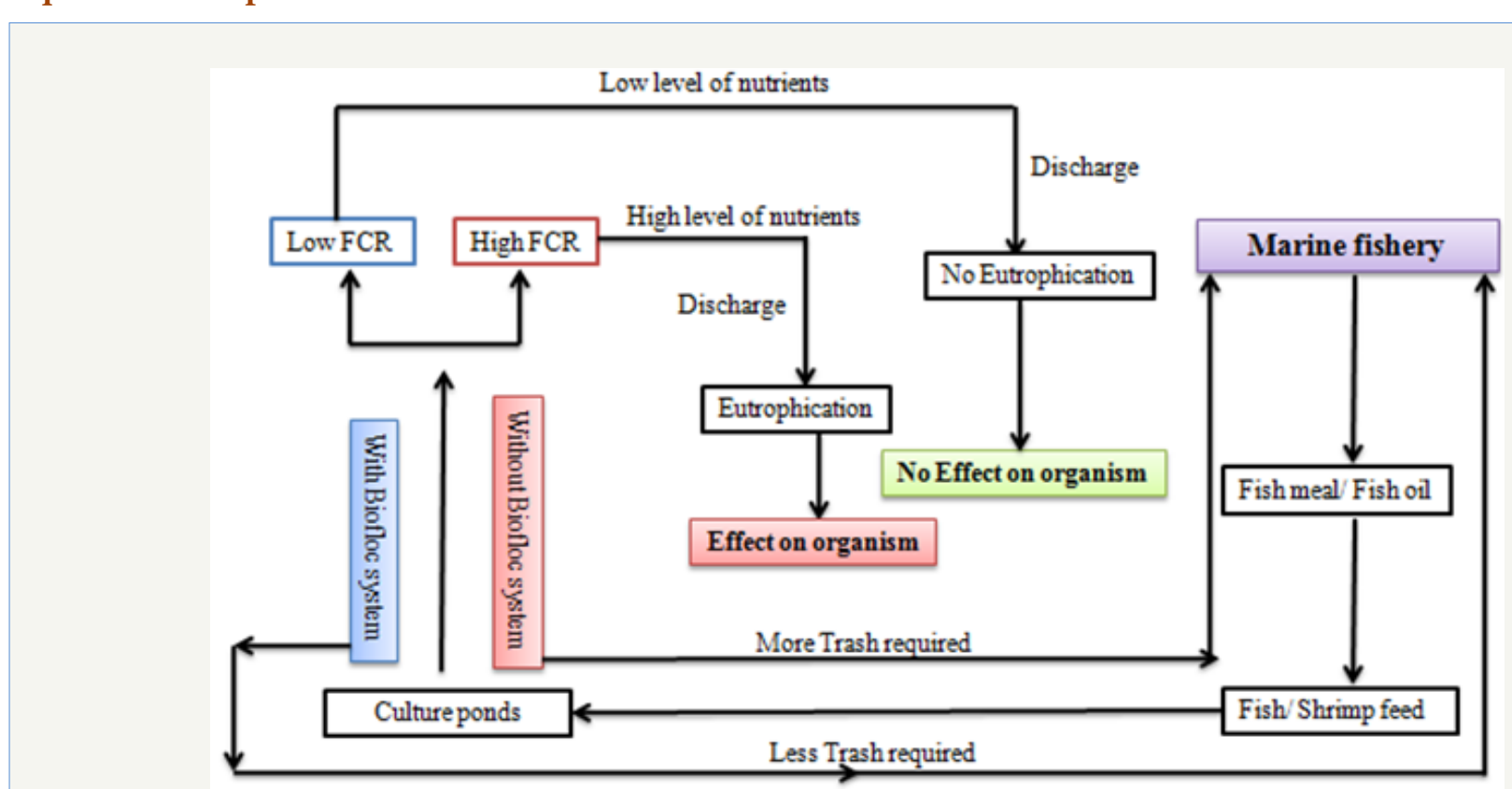

Figure 1: Positive Impact of Biofloc system on coastal (or) marine environment.

From last two decades, the production of post larvae and high protein pellet feeds increased and majorly contributed by Asian countries [32]. The discharges from aquaculture ponds have show negative impact on the creeks and coastal waters. The levels of nitrogen, phosphorus, biological and chemical oxygen demands which leads to effect on biota of the respective areas [33]. The change in the $\mathrm{pH}$ levels have also shows impact on organisms due to change in the physiological changes like enzymes, membrane processes etc $[34,35]$. Worldwide $50 \%$ of the mangroves were removed due to development of aquaculture. Moreover, these discharges were changes the water quality and change the productivity levels [36,37]. The countries like Vietnam $90 \%$ fish meal is imported and in feature required 2-3 times greater than the present level of usage
[38]. The implementation of BFT system in aquaculture sectors will be directly beneficiated as economically and indirectly support to eco-friendly (Figure 1). Feed production industries developing remarkably and they required more by products for the synthesis of pellet feeds. No doubt, for feature required more trawlers for catch and it leads to over exploitation as a result of change in the ecosystem and biodiversity as a direct impact and indirectly show impact on bio-geo-chemical cycles [39]. If the replacement of fish meal by using animal and plant proteins will be protect the marine ecosystems. From animals, among invertebrate sources like earthworms, zooplankton and silk warm pupae etc and from vertebrates, blood meal, meat and poultry products etc. From single cell proteins (bacteria and fungi), oil seeds (sunflower, soya been 
and cotton seed), legumes and corn meal also acts as potential replacers of fish meal [40]. Ray et al also suggested, synthesis feed from plant based proteins which contain high level of proteins and also less production of nitrogen and phosphorus wastes. Moreover, it is eco-friendly and also reduced over exploitation of marine fishery [41].

\section{Conclusion}

The aquaculture feed industries either directly (or) indirectly depends on marine fishery resources for the production of feed and other ingredients. By using Biofloc system, can produce same yield with minimal feed usage (or) less wastage. As a result, most of the marine niches can sustain as like same due to decrease of fishery resources utilization.

\section{References}

1. Browdy CL, Bratvold D, Stokes AD, Mcintosh RP (2001) Perspectives on the application of closed shrimp culture systems. In: Jory ED, Browdy CL (Eds.), The new Wave, Proceedings of the Special Session on Sustainable Shrimp Culture. The World Aquaculture Society, USA, pp. 20-34.

2. Schryver De P, Crab R, Defoirdt T, Boon N, Verstraete W, et al. (2008) The basics of bio-flocs technology: the added value for aquaculture. Aquaculture 277(3-4): 125-137.

3. Naylor RL, Goldburg RJ, Primavera JH, Kautsk N, Beveridge MC (2000) Effect of aquaculture on world fish supplies. Nature 405(6790): 10171024.

4. FIN (2007) A fishmeal information network issue summary. Latest news.

5. Anon (2004) How much wild fish does it really take to produce a tonne of salmon? Fishmeal Information Network Fact Sheet.

6. FAO (1986) FAO Fisheries Technical Paper-142, The production of fish meal and oil. Fisheries Technical Division, Food and Agriculture Organisation of the United Nations, Rome, pp. 1-63.

7. Ronnback P (2001) Shrimp Aquaculture- State of the Art. Swedish International Development agency (Sida), Stockholm \& Swedish EIA Centre, Swedish University of Agriculture sciences (SLU), Uppsala, Sweden, pp. 1-58.

8. Kautsky N, Beveridge M, Folke C, Primavera JH, Ronnback P et al. (2001) Aquaculture and Biodiversity. In: Levin S (Ed.), Encyclopaedia of Biodiversity. Academic Press, London, Vol 1, pp. 185-198.

9. Frid CLJ, Hansson S, Ragnarsson SA, Rijnsdorp A, Steingrimsson SA (1999) Changing levels of predation on benthos as a result of exploitation of fish populations. Ambio 28: 578-582.

10. Huntington TC, Hasan MR (2009) Fish as feed inputs for aquaculture practices, sustainability and implications: a global synthesis. In: Hasan MR, Halwart M (Eds.), Fish as feed inputs for aquaculture: practices, sustainability and implications. FAO Fisheries and Aquaculture Technical Paper, Rome, pp. 1-61.

11. Yoshitomi B (2001) Utilization of Antarctic krill for food and feed. In: Yoshitomi B (Ed.), Abstracts of the International Symposium on More Efficient Utilization of Fish and Fisheries Products, Kyoto, Japan. Graduate School of Agriculture, Kyoto University, Japan, p. 6.

12. Tacon Albert GJ, Marc Metian (2008) Global overview on the use of fish meal and fish oil in industrially compounded aqua feeds: Trends and future prospects. Aquaculture 285(1-4): 146-158.

13. (2016) Fishmeal and fish oil facts and figures. SEA FISH.

14. Emerenciano M, Cuzon G, Goguenheim J, Gaxiola G, Aquacop (2011) Floc contribution on spawning performance of blue shrimp Litopenaeus stylirostris. Aquac Res 44(1): 75-85.
15. Aquacop (1975) Maturation and spawning in captivity of penaeid shrimp: Penaeus merguiensis de Man, Penaeus japonicus Bate, Penaeus aztecus Ives, Metapenaeus ensis de Haan and Penaeus semisulcatus de Haan. In: Avault W, Miller R (Eds.), Proceedings of the Sixth Annual Meeting World Mariculture Society. Lousiana State University, Baton Rouge, pp. 123-129.

16. Sohier L (1986) Microbiologie appliquée àl'aquaculture marine intensive, pp. 119.

17. Yoram Avnimelech (1999) Carbon r nitrogen ratio as a control element in aquaculture systems. Aquaculture 176: 227-235.

18. Avnimelech Y (2007) Feeding with microbial flocs by tilapia in minimal discharge bioflocs technology ponds. Aquaculture 264(1-4): 140-147.

19. Avnimelech Y, Kochva M, Diab S (1994) Development of controlled intensive aquaculture systems with a limited water exchange and adjusted carbon to nitrogen ratio. Bamidgeh 46: 119-131.

20. Emerenciano M, Ballester ELC, Cavalli RO, Wasielesky W (2012) Biofloc technology application as a food source in a limited water exchange nursery system for pink shrimp Farfantepenaeus brasiliensis (Latreille, 1817). Aquac Res 43(3): 447-457.

21. Avnimelech Y (1999) Carbon and nitrogen ratio as a control element in aquaculture systems. Aquaculture 176(3-4): 227-235.

22. Peter Bossier, Julie Ekasari (2017) Biofloc technology application in aquaculture to support sustainable development goals. Microb Biotechnol 10(5): 1012-1016.

23. Ju ZY, Forster I, Conquest L, Dominy W, KuoWC, etal. (2008) Determination of microbial community structures of shrimp floc cultures by biomarkers and analysis of floc amino acid profiles. Aquac Res 39(2): 118-133.

24. Nunes AJP, Sa MVC, Andriola-Neto FF, Lemos D (2006) Behavioral response to selected feed attractants and stimulants in Pacific white shrimp, Litopenaeus vannamei. Aquaculture 260(1-4): 244-254.

25. Tacon AGJ, Cody JJ, Conquest LD, Divakaran S, Forster IP (2002) Effect of culture system on the nutrition and growth performance of Pacific white shrimp Litopenaeus vannamei (Boone) fed different diets. Aquacult Nutr 8(2): 121-137.

26. Ju ZY, Foresters I, Conquest L, Dominy W, Kuo WC, et al. (2008) Determination of microbial community structures of shrimp floc cultures by biomarkers ad analysis of floc amino acids profiles. Aquac Res 39(2): 118-133.

27. Crab R, Lambert A, Defoirdt T, Bossier P, Verstraete W, et al. (2010) The application of bioflocs technology to protect brine shrimp (Artemia franciscana) from pathogenic Vibrio harveyi. J Appl Microbiol 109(5): 1643-1649.

28. Yusuf MW, Utomo NBP, Yuhana M, Widanarni (2015) Growth Performance of Catfish (Clarias gariepinus) in Biofloc-Based Super Intensive Culture Added with Bacillus sp. Journal of Fisheries and Aquatic Science 10(6): 523-532.

29. Nyan T, Hendri F, Naira T, Kaesar S (2008) Partial harvest/ biofoc system: Promising for Pacific white shrimp. Global Aquaculture Advocate, pp. 84-86.

30. Nyan T, Hendri F, Nairgan T, Kaesar S (2009) Partial harvest with BFT, a promising system Pacific white shrimp. World Aquaculture, pp. 25-29.

31. John A Hargreaves (2013) Biofloc Production Systems for Aquaculture. SRAC Publication, USA.

32. Jacques F, Jean-Louis MM, Nguyen T (1999) An Impact of tropical shrimp aquaculture on the environment in Asia and the Pacific. Shrimp Culture 12(4): 9-13.

33. Bui TD, Jim LV, Austin MC (2012) Impact of Shrimp Farm Effluent on Water Quality in Coastal Areas of the World Heritage-Listed Ha Long Bay. American Journal of Environmental Sciences 8(2): 104-116. 
34. Boyd CE, Tucker CS (1998) Pond Aquaculture Water Quality Management. In: Boyd CE, Tucker CS (Eds.), Pond Aquaculture Water Quality Management. ( $1^{\text {st }}$ edn), Boston, Kluwer Academic, London, pp. 700.

35. Armcanz A (2000) Australian and New Zealand Guidelines for Fresh and Marine Water Quality. Australian and New Zealand Environment and Conservation Council and Agriculture and Resource Management Council of Australia and New Zealand, Canberra.

36. Primavera JH (1998) Tropical shrimp farming and its sustainability. In: de Silva S (Ed.), Tropical Mariculture. Academic Press, London, pp. 257289.

37. Hamilton L, Dixon J, Miller G (1989) Mangroves: an undervalued resource of the land and sea. Ocean Year book 8: 254-288.
38. Edwards P, Tuan LA, Allan GL (2004) A survey of marine trash fish and fish meal as aquaculture feed ingredients in Vietnam. ACIAR Working p. 57.

39. Biju Kumar A, Deepthi GR (2006) Trawling and by-catch: Implications on marine ecosystem. Current Science 90(7): 10.

40. Michael B (2002) Use of Fishmeal and Fish Oil in Aqua feeds. FAO.

41. Ray AJ, Lewis BL, Browdy CL, Leffler JW (2010) Suspended solids removal to improve shrimp (Litopenaeus vannamei) production and an evaluation of a plant-based feed in minimal-exchange, superintensive culture systems. Aquaculture 299(1-4): 89-98. 